\title{
Review Article \\ Phytoremediation of Nitrogen as Green Chemistry for Wastewater Treatment System
}

\author{
Lennevey Kinidi and Shanti Salleh \\ Department of Chemical Engineering and Energy Sustainability, Faculty of Engineering, Universiti Malaysia Sarawak, \\ 94300 Kota Samarahan, Sarawak, Malaysia
}

Correspondence should be addressed to Shanti Salleh; sshanti@feng.unimas.my

Received 27 February 2017; Accepted 2 May 2017; Published 30 May 2017

Academic Editor: Donald L. Feke

Copyright (C) 2017 Lennevey Kinidi and Shanti Salleh. This is an open access article distributed under the Creative Commons Attribution License, which permits unrestricted use, distribution, and reproduction in any medium, provided the original work is properly cited.

\begin{abstract}
It is noteworthy that ammoniacal nitrogen contamination in wastewater has reportedly posed a great threat to the environment. Although there are several conventional technologies being employed to remediate ammoniacal nitrogen contamination in wastewater, they are not sustainable and cost-effective. Along this line, the present study aims to highlight the significance of green chemistry characteristics of phytoremediation in nitrogen for wastewater treatment. Notably, ammoniacal nitrogen can be found in many types of sources and it brings harmful effects to the environment. Hence, the present study also reviews the phytoremediation of nitrogen and describes its green chemistry characteristics. Additionally, the different types of wastewater contaminants and their effects on phytoremediation and the phytoremediation consideration in wastewater treatment application and sustainable waste management of harvested aquatic macrophytes were reviewed. Finally, the present study explicates the future perspectives of phytoremediation. Based on the reviews, it can be concluded that green chemistry characteristics of phytoremediation in nitrogen have proved that it is sustainable and cost-effective in relation to other existing ammoniacal nitrogen remediation technologies. Therefore, it can be deduced that a cheaper and more environmental friendly ammoniacal nitrogen technology can be achieved with the utilization of phytoremediation in wastewater treatment.
\end{abstract}

\section{Introduction}

Ammoniacal nitrogen is one of the wastewater contaminants, which can be found in many types of wastewater. Excessive ammoniacal nitrogen in water body may lead to eutrophication, which induces the growth and decay of excessive plant and algal, and caused degradation of the water quality [1]. Notably, algal blooms may limit light penetration. On the other hand, eutrophication promotes anoxia in the water body, which leads to unpleasant and injurious gases, and endangers fish and invertebrates [1]. To date, there are several current methods being employed for the removal of ammoniacal nitrogen in wastewater. Ammoniacal nitrogen may be removed by means of conventional air stripping tower, which can only remove around $60 \%$ to $90 \%$ ammoniacal nitrogen. However, it should be noted that this process requires the use of chemicals for $\mathrm{pH}$ value control, therefore imposing higher treatment cost and lime-related operating and maintenance problems. Apart from the conventional air stripping tower, ammoniacal nitrogen can also be removed with break-point chlorination. This process is able to remove $90 \%$ to $100 \%$ of ammoniacal nitrogen, but it generates high chlorine residual and can be detrimental to the aquatic life. In addition, it requires careful control of the $\mathrm{pH}$ value in order to prevent the formation of nitrogen trichloride gas.

To date, phytoremediation is regarded as one of the most economically viable, sustainable, and affordable technologies. This is due to the fact that plants-based systems and microbiological processes were utilized in phytoremediation to reduce pollutants in nature [2]. It is an in situ remediation technology, which is ecologically friendly and solar dependent clean-up technology [2]. It is noteworthy that phytoremediation is a green chemistry process which offers a sustainable alternative and cost-effective technology 
in relation to conventional ammoniacal nitrogen clean-up technology for industrial tertiary wastewater treatment. Consequently, the present study aims to highlight the significance of green chemistry characteristics and the sustainability of phytoremediation in nitrogen remediation for wastewater treatment.

\section{Ammoniacal Nitrogen: Sources and Effect in the Environment}

Ammonia is colourless gas and exhibits a pungent smell at ambient temperature and pressure. It is the main constituent of domestic wastewater concentrations. It is very soluble in water and exists in equilibrium between ionized ammonia (NH3) and ionized ammonia (NH4+) species in water [3]. A number of studies indicated that the total ammonia toxicity is caused by the effect of unionized $\mathrm{NH}_{3}$ [3]. Total ammonia is usually referred to as the summation of ammonia and ammonium concentrations [4]. The ammonium ions is an important element, which is needed in plants for growth. Notably, ammonia enters the environment by means of the municipal, agricultural, industrial, and also natural activities [5]. Also, ammonia enters the environment from natural sources due to the degradation of organic waste matter, gas exchange with atmosphere, animal waste, and nitrogen fixation [6]. There are two types of sources on how ammonia enters the environment, namely, point and nonpoint sources. Point sources of ammonia derive from the emissions and effluent from various types of industrial plants. On the other hand, the nonpoint sources of ammonia are from agricultural, residential, municipal, and atmospheric releases [6].

The presence of ammoniacal nitrogen in water leads to environmental problems, such as eutrophication of surface water, changes in ecosystems, and acidifications [43]. In aquatic eutrophication, the ammoniacal nitrogen works as a source of nitrogen, which is needed for the production of nitrates. The high concentration of nitrates and ammonia in water body may result in a toxic environment and may cause oxygen deficiency environments resulting from the nitrification process. Severe eutrophication may lead to a hypoxic condition, which is a dead zone where no aquatic life can survive [43].

\section{Phytoremediation of Ammoniacal Nitrogen}

The plant utilization of nitrogen involves few steps including the uptake, assimilation, and translocation [44]. Plants take up mainly three forms of nitrogen, namely, nitrate ions, urea, and ammonium ions. Once ammonia is present in the plant cell, it is incorporated into proteins and other organic combinations through a biochemical reaction. However, only the ammonium ion is assimilated into the organic molecules in the plant tissues by means of enzymatic process [44]. Ammonium and nitrate ions are the principal sources of nitrogen for plant growth and are necessary in larger amount than the other mineral nutrients. In comparison to nitrate, ammonium is absorbed by the plants more quickly [45]. This is due to the lower energy requirement for the uptake and assimilation of ammonium ions in relation to the nitrate ions [46].
It should be noted that the ammonium ions can be directly absorbed by the roots of the plants or as a result of nitrate ion reduction, it is further assimilated into the amide amino group of glutamine by the glutamine synthetase and subsequently, into glutamic acid by the glutamate synthase. These two enzymes resulted in the assimilation of most of the ammonium ions [44]. Notably, the ammonium ions are toxic and not permitted to be stored in plants. Hence, the ammonium ions are either oxidized nitrates ions, assimilated to produce amino acids, or converted to amides [47].

When the plants take up ammonium ions, they release one hydrogen ion in the medium solutions. Over time, the uptake of ammoniacal nitrogen may increase the hydrogen ions concentration, hence decreasing the growing medium $\mathrm{pH}$ value. However, an increase of ammonium uptake in plants and storage may result in cell damage and further leads to cell death [48]. The ammonium ions are taken up by the plants from the root uptake. The nitrogen uptake by the root system depends on the nitrogen demand of the entire plant and is dependent on the nitrogen requirement for growth. Nitrogen starvation of plants for several days may lead to the increased capacity for ammonium uptake [48].

\section{Green Chemistry Characteristics of Phytoremediation}

Green chemistry is defined as the chemical products and processes that lessen or prevent the production of hazardous substances. The application of green chemistry does not only bring benefits to the environment, but also lead to innovation and enhanced economy [49]. In phytoremediation, only plants were needed for the remediation process. It should be noted that phytoremediation of ammoniacal nitrogen process possessed green chemistry characteristics, such as no chemical usage, energy efficient, and safer reaction condition in relation to the conventional ammoniacal remediation technology.

4.1. No Chemical Usage. In comparison to conventional ammoniacal nitrogen remediation technology, the phytoremediation process requires no chemical usage. The chemicals required for the conventional ammoniacal remediation technology may add up additional operational cost. This cost is considered as a loss as it does not add up to the company's profit. Notably, no chemical is needed for phytoremediation process. The plants naturally take up ammonium ions from the wastewater to support its growth. Besides that, the plants used in phytoremediation are renewable feedstock that aids in the reduction on climate change by the fixation of carbon dioxide [50]. The existing ammoniacal nitrogen remediation technology and phytoremediation with the chemical required for each process are presented in Table 1.

Ferraz et al. (2013) employed lime and powdered calcium hydroxide to increase the $\mathrm{pH}$ value to 11 of the leachate for ammonia stripping, in which the ammonia stripping tower reduces at $88 \%$ of the initial TAN concentration in the $\mathrm{pH}$ value of 11 leachate [7]. However, the formation of calcium carbonate scale resulted in the reduction of ammonia stripping performance [51]. Viotti and Gavasci (2014) revealed 
TABLE 1: Chemical used for different types of ammoniacal nitrogen remediation technology.

\begin{tabular}{lcc}
\hline Technology & Type of chemical & Reference \\
\hline Air stripping & Lime \& powdered $\mathrm{Ca}(\mathrm{OH})_{2}$ & {$[7]$} \\
Ion exchange & Saturated lime solution, $\mathrm{NaCl}$ and sodium hydroxide, cliniptilolite & {$[8]$} \\
Breakpoint chlorination & Chlorine gas \& lime & {$[9]$} \\
Electrodialysis & Electrolyte (sodium sulphate, potassium chloride) & {$[10]$} \\
Phytoremediation & No chemical is needed & {$[11]$} \\
\hline
\end{tabular}

TABLE 2: Comparison on the energy consumption of the existing ammoniacal remediation and phytoremediation.

\begin{tabular}{lcc}
\hline Technology & Energy usage & Reference \\
\hline Ammonia stripping & $450 \mathrm{MJ} / \mathrm{m}^{3}$ per leachate treated & {$[12]$} \\
Breakpoint chlorination & $17.4 \mathrm{million} \mathrm{kwh} / \mathrm{yr}$ (electricity cost) & {$[13]$} \\
Biological nitrification & $6.31 \mathrm{million} \mathrm{kWh} / \mathrm{yr}$ (electricity cost) & {$[13]$} \\
Ion exchange & $126-194 \mathrm{MJ}$ per $\mathrm{NH}_{4}-\mathrm{N}$ treated & {$[8]$} \\
Phytoremediation & Harvest energy from sunlight & {$[14]$} \\
\hline
\end{tabular}

that progressive scaling reduces the ammonia removal efficiency by $18 \%$ of the ammonia stripper [51]. It is noteworthy that ion exchange for the removal of ammoniacal nitrogen utilized regenerant for the regeneration of the clinoptilolite. Interestingly, the costs of chemicals, which are required for regeneration made up a major fraction of the cost of ion exchange process [8]. As regards the removal ammoniacal nitrogen using break-point chlorination, chlorine gas and lime are used. The total costs of the chemicals for breakpoint chlorination for $300 \mathrm{MGD}$ with $15 \mathrm{mg} / \mathrm{L}$ of ammoniacal nitrogen influent plant are 1.47 cents/1000 L of wastewater [9]. Mondor et al. (2007) used sodium sulphate and potassium chloride as the electrolytes for the electrodialysis of swine manure for ammonia recovery [10]. Notably, phytoremediation requires no chemical usage during the remediation process and this can save up the company's operational cost. It is easy for aquatic macrophytes to be cultured for stock due to its fast growth and reproduction.

4.2. Reduction of Energy Consumption. As regards wastewater treatment plant, energy consumption is often associated with the amount of type and load of the pollutant. On average, nutrient removal technology has higher energy intensity [52]. Notably, phytoremediation is a solar-driven technology and hence, only the energy from sunlight is required for the phytoremediation process. The sunlight energy can be found in abundance all year round, especially in the countries with tropical climate. It should be noted that phytoremediation offers a relatively lower energy usage than the other existing ammoniacal nitrogen remediation technologies. Table 2 indicates the comparison on the energy consumption of the different types of ammoniacal nitrogen technology.

4.3. Inherently Safer Process. In comparison to some conventional ammoniacal nitrogen clean-up technologies, phytoremediation has safer reactions and lower risks. Phytoremediation provides an alternative to remediate ammoniacal nitrogen by means of using eco-friendly biomass rather than chemicals, which caused potential risks such as health hazards, chemical reaction hazards, fire and explosion hazards, and environmental hazards. Table 3 indicates the potential risk arising from the utilization of conventional ammoniacal nitrogen clean-up technology.

Many risk assessment studies have reported accidents involving ammonia with many subjects [53]. Campos et al. (2013) in their study of the evaluation of $\mathrm{pH}$ value, alkalinity, and temperature during the air stripping process for ammonia removal from landfill leachate bubbled the ammonia gas generated from ammonia stripping in acid for neutralizations [15]. Besides that, break-point chlorination may result in the generation of nitrogen trichloride, which is an explosive gas. Okado et al. (2014) reported in their study of analysis of an explosion accident of nitrogen trichloride in waste liquid containing ammonium ion and platinum black that the explosion of the liquid waste was due to the generation of nitrogen chloride [16]. Notably, there were no potential risks associated with phytoremediation, biological nitrification, and ion exchange process.

\section{Wastewater Contaminants and Effects to Phytoremediation Performance}

It is worth highlighting that the success of phytoremediation application for the industrial tertiary wastewater treatment, especially for nitrogen removal, is highly dependent on the characteristics of tertiary wastewater effluent. The industrial wastewater is comprised of a wide range of contaminants, which may cause toxicity to the aquatic macrophytes. Toxic contaminants that are present in the wastewater may inhibit the growth of the plants, which may affect the performance of the aquatic macrophytes in remediating the wastewater. According to Clarke and Baldwin (2002), different tolerance on ammonia concentrations was exhibited with different types of aquatic macrophytes and they concluded that the effectiveness of phytoremediation can be improved by choosing the aquatic macrophytes which have high tolerance 
TABLE 3: Different types of existing ammoniacal nitrogen remediation technology with different potential hazard.

\begin{tabular}{lcc}
\hline Technology & Potential hazard & References \\
\hline Ammonia stripping & Generation of corrosive by-product (ammonia) & {$[15]$} \\
Breakpoint chlorination & Generation explosive by-product (nitrogen trichloride) & [16] \\
Biological nitrification & Not reported & - \\
Ion exchange & Not reported & - \\
Phytoremediation & No generation of harmful by-product & {$[17]$} \\
\hline
\end{tabular}

of ammonia level in the wastewater [54]. Besides that, the tolerance of aquatic macrophytes on different types of contaminants present on the wastewater may also affect the ammoniacal nitrogen removal efficiency. According to Lu et al. (2004), reduced growth can be observed on the plants under heavy metal stress [18]. Apart from that, exposure to heavy metals in wastewater may also inhibit plant's growth [55]. It is worth noting that the level of tolerance in different types of aquatic macrophytes with different ammoniacal nitrogen concentrations and other common wastewater contaminants were studied by several researchers. Table 4 displays some research carried out on tolerances of several aquatic macrophytes used for phytoremediation with different types of contaminants.

As shown in Table 4, different types of aquatic macrophytes have different tolerance with different types of wastewater contaminants. Eichhornia crassipes appears to be one of the most promising aquatic plants for tertiary industrial wastewater treatment due to its high tolerance with wide range of wastewater contaminants. Notably, it has high tolerance to most of the heavy metals and higher tolerance to higher ammoniacal nitrogen concentrations.

\section{Phytoremediation Wastewater Treatment Application Consideration}

The important parameters of phytoremediation must be considered to ensure the efficiency of the phytoremediation process. Among the important parameters are aquatic macrophytes species, salinity, temperature, and $\mathrm{pH}$.

6.1. Aquatic Macrophytes Species. To date, a number of studies have been carried out on ammoniacal nitrogen uptake with different type of macrophyte species for wastewater treatment. In determining the suitability of macrophyte species to be utilized for phytoremediation, the rate of ammonium uptake by plants and the assimilation of these nutrients into the plant biomass are of utmost importance. The generated plant biomass may be utilized as an indicator to estimate the nutrient uptake capacity of the plants [56]. Table 4 indicates the list of macrophytes used by different researchers for the phytoremediation of ammoniacal nitrogen. However, the suitability of the aquatic macrophytes for different types of wastewater depends on the aquatic macrophytes tolerance on different types of contaminants in the wastewater as shown in Table 4.

6.2. Salinity. The effect of salinity stress on aquatic macrophytes may greatly affect the growth and reproduction of aquatic plants. Different types of aquatic macrophytes species have different tolerance range. According to Haller et al. (1974), the tolerance of aquatic macrophytes towards salinity may affect their performance in water treatment due to the reduction of transpiration and total dry weight with higher level of salinity and death [57]. According to Haller et al. (1974), large-leaved floating species is the most vulnerable to salinity, whereas submerged species may tolerate high level of salinity in comparison to large-leaved ones, and smallleaved species is the least vulnerable [57]. According to a study carried out by Lu (2009), salinity has a significant effect on plants dry biomass [58]. This is due to the fact that more new individuals of small size plant may not compensate for the biomass reduction due to the inhibited vegetative growth at high salinity level [58]. Notably, this high salinity level inhibits aquatic macrophytes water uptake by reducing the osmotic potential of the water. Haller et al. (1994) observed that Pistia stratiotes and Eichhornia crassipes may be significantly affected by lower salinities, which are around $10 \%$ and $13.32 \%$, respectively [57]. Moreover, Lu (2009) observed that the Pistia stratiotes dry matter yield was reduced by approximately $30 \%$ in the $1766 \mu \mathrm{S} \mathrm{cm}^{-1}$ [58]. On the other hand, Pascale et al. (1997) observed that biomass production is inhibited at higher salinity [59].

6.3. Temperature. The performance of aquatic macrophytes in phytoremediation varies with temperature [60]. This is due to the fact that the phytoremediation performance of plants is dependent on the plants' growth. Temperature is one of the most crucial ecological factors, which influence the productivity of a particular macrophyte species. Most of aquatic macrophytes are able to grow well between the temperatures of $20^{\circ} \mathrm{C}$ and $30^{\circ} \mathrm{C}$ and inhibited growth at the temperature of $10^{\circ} \mathrm{C}$ and below [61]. Shah et al. (2013) studied the performance of three aquatic macrophytes, which include Eichhornia crassipes, Lemna minor, and Pistia stratiotes regarding BOD5 removal. It was found that the optimum temperature for the three aquatic macrophytes' growth ranges between $15^{\circ} \mathrm{C}$ and $38^{\circ} \mathrm{C}$ [60]. Nevertheless, different species of aquatic macrophytes may be used for cooler weather conditions. Reddy and Tucker (1985) stated that Centella asiatica can be successfully grown during cooler months and may be used to replace Eichhornia crassipesbased nitrogen wastewater treatment system [62].

6.4. $p H$. Wastewater $\mathrm{pH}$ value may influence the performance of aquatic macrophytes in remediating the ammoniacal nitrogen. Shah et al. (2014) reported that a $\mathrm{pH}$ value of 6-9 
TABLE 4: Different types of contaminants with different aquatic macrophytes species.

\begin{tabular}{|c|c|c|c|c|}
\hline $\begin{array}{l}\text { Type of } \\
\text { contaminants }\end{array}$ & Aquatic macrophytes & $\begin{array}{l}\text { Tolerance } \\
\mathrm{Mg} / \mathrm{L}\end{array}$ & Comments & References \\
\hline \multirow{6}{*}{ Cadmium } & & & $\begin{array}{c}\text { Reduction of relative growth in } \\
\text { cadmium }>2 \mathrm{mg} / \mathrm{L} \text { concentrations. }\end{array}$ & [18] \\
\hline & Eichhornia crassipes & $<20$ & $\begin{array}{l}\text { Survived } 21 \text { days in the high } \\
\text { concentrations of cadmium }(5 \mathrm{mg} / \mathrm{L} \text {, } \\
10 \mathrm{mg} / \mathrm{L}, 15 \mathrm{mg} / \mathrm{L} \text {, and } 20 \mathrm{mg} / \mathrm{L}) \text { with } \\
\text { toxicity in the form of chlorosis, gross } \\
\text { necrosis, and wilting of older leaves. }\end{array}$ & [19] \\
\hline & & $<0.11$ & $\begin{array}{c}\text { Survived } 7 \text { days of test period with } 50 \% \\
\text { of inhibition of growth rate at } \\
\text { concentrations } 0.11 \mathrm{mg} / \mathrm{L} .\end{array}$ & \multirow{2}{*}[20]{} \\
\hline & Lemna minor & $<0.56$ & $\begin{array}{c}\text { Survived } 7 \text { days of test period with } 50 \% \\
\text { of inhibition of growth rate at } \\
\text { concentrations } 0.56 \mathrm{mg} / \mathrm{L} .\end{array}$ & \\
\hline & Ipomea aquatica & $<22.7$ & $\begin{array}{l}\text { Survived } 15 \text { days in zinc concentration } \\
\text { of } 0.23 \mathrm{mg} / \mathrm{L}, 2.27 \mathrm{mg} / \mathrm{L}, 4.09 \mathrm{mg} / \mathrm{L} \text {, } \\
7.26 \mathrm{mg} / \mathrm{L}, 12.71 \mathrm{mg} / \mathrm{L} \text {, and } 22.7 \mathrm{mg} \cdot \mathrm{L} \\
\text { with blackening of roots. }\end{array}$ & [21] \\
\hline & Pistia stratiotes & $<10.5$ & $\begin{array}{l}\text { Survived } 14 \text { days of experiment with } \\
\text { yellowing, chlorosis at } 10.5 \mathrm{mg} / \mathrm{L} .\end{array}$ & {$[22]$} \\
\hline Cyanide & Eichhornia crassipes & $<10$ & $\begin{array}{l}\text { At } 5 \mathrm{mg} / \mathrm{L} \text { of } \mathrm{CN} \text {, the transpiration } \\
\text { slightly reduced with no morphological } \\
\text { changes and plants exposed to } 10 \mathrm{mg} / \mathrm{L} \\
\text { of } \mathrm{CN} \text { survived with } 50 \% \text { desiccation of } \\
\text { their leaves. }\end{array}$ & [23] \\
\hline \multirow{4}{*}{ Zinc } & Elodea canadensis & $<0.33$ & $\begin{array}{c}\text { Survived } 7 \text { days of test period with } 50 \% \\
\text { of inhibition of growth rate at } \\
\text { concentrations } 0.33 \mathrm{mg} / \mathrm{L} .\end{array}$ & \multirow{3}{*}[20]{} \\
\hline & Leptodictyum riparium & $<6.54$ & $\begin{array}{l}\text { Survived } 7 \text { days of test period with } 50 \% \\
\text { of inhibition of growth rate at } \\
\text { concentrations of } 6.54 \mathrm{mg} / \mathrm{L} .\end{array}$ & \\
\hline & Lemna minor & $<6.54$ & $\begin{array}{l}\text { Survived } 7 \text { days of test period with } 50 \% \\
\text { of inhibition of growth rate at } \\
\text { concentrations } 6.54 \mathrm{mg} / \mathrm{L} .\end{array}$ & \\
\hline & Eichhorna crassipes & $<12$ & $\begin{array}{l}\text { Growth rate reduced in } 2-5 \mathrm{ppm} \text { of } \\
\text { selenium and becomes negative at } \\
\text { higher concentrations between } 8 \mathrm{mg} / \mathrm{L} \\
\text { and } 12 \mathrm{mg} / \mathrm{L} \text {. }\end{array}$ & {$[24]$} \\
\hline \multirow{2}{*}{ Selenium } & Eichhornia crassipes & $<24$ & $\begin{array}{l}\text { Growth slightly decreased at higher } \\
\text { concentration between } 16 \text { and } 24 \mathrm{mg} / \mathrm{L} \text {. }\end{array}$ & \multirow{2}{*}[25]{} \\
\hline & Pistia stratiotes & $<40$ & $\begin{array}{l}\text { Yellowing of leaves at } 40 \mathrm{mg} / \mathrm{L} \text { of } \\
\text { selenium at day } 4 .\end{array}$ & \\
\hline \multirow{5}{*}{ Copper } & Leptodictyum riparium & $<0.64$ & $\begin{array}{l}\text { Survived } 7 \text { days of test period with } 50 \% \\
\text { of inhibition of growth rate at } \\
\text { concentrations } 0.64 \mathrm{mg} / \mathrm{L} .\end{array}$ & \multirow{4}{*}[20]{} \\
\hline & Lemna minor & $<0.32$ & $\begin{array}{c}\text { Survived } 7 \text { days of test period with } 50 \% \\
\text { of inhibition of growth rate at } \\
\text { concentrations } 0.32 \mathrm{mg} / \mathrm{L} .\end{array}$ & \\
\hline & Elodea canadensis & $<0.51$ & $\begin{array}{c}\text { Survived } 7 \text { days of test period with } 50 \% \\
\text { of inhibition of growth rate at } \\
\text { concentrations } 0.51 \mathrm{mg} / \mathrm{L} .\end{array}$ & \\
\hline & Lemna minor & $<1.04$ & $\begin{array}{c}\text { Survived } 7 \text { days of test period with } 50 \% \\
\text { of inhibition of growth rate at } \\
\text { concentrations } 1.04 \mathrm{mg} / \mathrm{L} .\end{array}$ & \\
\hline & Eichhorna crassipes & $<25$ & $\begin{array}{l}\text { Survived } 7 \text { days of experiment with } \\
\text { signs of copper toxicity such as leaf and } \\
\text { petiole chlorosis. }\end{array}$ & {$[26]$} \\
\hline
\end{tabular}


TABLE 4: Continued.

\begin{tabular}{|c|c|c|c|c|}
\hline $\begin{array}{l}\text { Type of } \\
\text { contaminants }\end{array}$ & Aquatic macrophytes & $\begin{array}{c}\text { Tolerance } \\
\mathrm{Mg} / \mathrm{L}\end{array}$ & Comments & References \\
\hline \multirow{4}{*}{ Lead } & Leptodictyum riparium & $<2.07$ & $\begin{array}{l}\text { Survived } 7 \text { days of test period with } 50 \% \\
\text { of inhibition of growth rate at } \\
\text { concentrations } 2.07 \mathrm{mg} / \mathrm{L} .\end{array}$ & \multirow[b]{2}{*}[27]{} \\
\hline & Elodea canadensis & $<1.04$ & $\begin{array}{c}\text { Survived } 7 \text { days of test period with } 50 \% \\
\text { of inhibition of growth rate at } \\
\text { concentrations } 1.04 \mathrm{mg} / \mathrm{L} .\end{array}$ & \\
\hline & Eichhornia crassipes & $<1000$ & $\begin{array}{l}\text { Survived } 7 \text { days of treatment test at } \\
1000 \mathrm{mg} / \mathrm{L} \text { with inhibited plant growth } \\
\text { by } 50 \% .\end{array}$ & {$[28]$} \\
\hline & Pistia stratiotes & $<414$ & $\begin{array}{c}\text { After } 8 \text { days, plant destruction was } \\
\text { observed, leaves and roots falling at } \\
414 \mathrm{mg} / \mathrm{L} \text {. }\end{array}$ & {$[22]$} \\
\hline \multirow[b]{2}{*}{ COD } & Eichhornia crassipes & $<1530$ & $\begin{array}{l}\text { Survived } 7 \text { days in the } 1530 \mathrm{mg} / \mathrm{L} \text { of } \\
\text { COD of textile effluent with slightly } \\
\text { brown leaves. }\end{array}$ & [29] \\
\hline & Pistia stratiotes & $<1931$ & $\begin{array}{l}\text { At } 1931 \mathrm{mg} / \mathrm{L} \text { of COD of parboiled rice } \\
\text { mill wastewater, the color of the plant } \\
\text { changed to brown by the second day } \\
\text { and wilted on the } 5 \text { th day. }\end{array}$ & {$[27]$} \\
\hline \multirow[b]{2}{*}{ BOD } & Eichhornia crassipes & $<2121$ & $\begin{array}{l}\text { At } 2121 \mathrm{mg} / \mathrm{L} \text { of BOD of tapioca } \\
\text { wastewater, Eichhornia crassipes } \\
\text { survived until day } 8 \text { by } 20 \% \text {. }\end{array}$ & {$[30]$} \\
\hline & Pistia stratiotes & $<1089$ & $\begin{array}{l}\text { At } 1089 \mathrm{mg} / \mathrm{L} \text { of COD of parboiled rice } \\
\text { mill wastewater, the color of the plant } \\
\text { changed to brown by the second day } \\
\text { and wilted on the } 5 \text { th day. }\end{array}$ & {$[27]$} \\
\hline \multirow{5}{*}{$\begin{array}{l}\text { Ammoniacal } \\
\text { nitrogen }\end{array}$} & Eichhornia crassipes & $<56.4$ & $\begin{array}{c}\text { Survived } 4 \text { weeks of test period with } \\
\text { wilting, loss of plant turgidity, weakness } \\
\text { of petioles, and browning and reduction } \\
\text { in lead number in raw sewage. }\end{array}$ & [31] \\
\hline & Eichhornia crassipes & $<136$ & $\begin{array}{l}\text { Survived } 4 \text { weeks of test period in the } \\
\text { ammoniacal nitrogen concentrations of } \\
136 \mathrm{mg} / \mathrm{L} \text { in dairy manure. }\end{array}$ & {$[32]$} \\
\hline & Hydrocotyle umbellata & $<136$ & $\begin{array}{l}\text { Wilt on the } 7 \text { th day of the test period } \\
\text { with crisping and browning at } 136 \mathrm{mg} / \mathrm{L} \\
\text { of ammoniacal nitrogen concentrations } \\
\text { of dairy manure. }\end{array}$ & {$[32]$} \\
\hline & Lemna minor & $<7.2$ & $\begin{array}{l}50 \% \text { growth inhibition at unionized } \\
\text { ammonia concentrations of } 7.2 \mathrm{mg} / \mathrm{L} \text {. }\end{array}$ & {$[33]$} \\
\hline & Pistia stratiotes & $<136$ & $\begin{array}{l}\text { Wilt on the } 7 \text { th day of the test period } \\
\text { with crisping and browning at } 136 \mathrm{mg} / \mathrm{L} \\
\text { of ammoniacal nitrogen concentrations } \\
\text { of dairy manure. }\end{array}$ & {$[32]$} \\
\hline
\end{tabular}

is the most favourable for the treatment of wastewater using aquatic macrophytes [60]. El-Gendy et al. (2004) in their study use Eichhornia crassipes, Pistia stratiotes, and Lemna minor to remediate municipal wastewater and reported that the optimal growth for Eichhornia crassipes is 7 [63]. However, it can withstand $\mathrm{pH}$ values ranging from 4 to 10 [63].

\section{Harvesting Aquatic Macrophytes}

It should be noted that the major issue with regard to phytoremediation is the large amount of biomass generated from this process. The most effective ammoniacal nitrogen removal deals with the harvested aquatic at the end of each vegetation cycle. Failure to harvest the aquatic macrophytes at its harvesting period may lead to the release of the stored ammoniacal nitrogen back into the wastewater.

7.1. Aquatic Macrophytes Biomass Yield. Aquatic macrophytes generated a large amount of biomass under nutrient-rich conditions [64]. To anticipate the amount of waste that will be generated, the amount of biomass-generated data is crucial. Also, this preliminary data is important in selecting the most 
TABLE 5: Biomass yield for different types of aquatic macrophytes.

\begin{tabular}{lcc}
\hline Aquatic macrophytes & Maximum annual biomass yield (t dry wt $\left.\mathrm{m}^{2} \mathrm{yr}^{-1}\right)$ & References \\
\hline Eichhornia crassipes & 0.0106 & [34] \\
Pistia stratiotes & 0.0072 & [34] \\
Hydrocotyle umbellata & 0.0041 & [34] \\
Phragmites communis & 0.0010 & {$[35]$} \\
Lemna minor & 0.0008 & [36] \\
Salvinia rotundifolia & 0.0030 & [37] \\
\hline
\end{tabular}

TABLE 6: Leaf lifespan of different types of aquatic macrophytes.

\begin{tabular}{lcc}
\hline Aquatic macrophytes & Maximum leaf life span (days) & References \\
\hline Eichhornia crassipes & 35 & {$[38]$} \\
Nymphaea tetragona Georgi & 31 & {$[39]$} \\
Trapa natans & 30 & {$[40]$} \\
Hydrocharis dubia L. & 18 & {$[41]$} \\
Lemna minor & 31 & {$[42]$} \\
Spirodela polyrhiza & 12 & {$[42]$} \\
Wolffia borealis & 12 & {$[42]$} \\
\hline
\end{tabular}

appropriate waste management technique for phytoremediation. Notably, different types of aquatic macrophytes have different biomass yield as exhibited in Table 5 .

Based on Table 5, Eichhornia crassipes has the highest

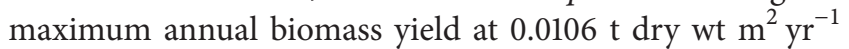
and Lemna minor has the lowest maximum annual biomass yield at $0.0008 \mathrm{t}$ dry wt $\mathrm{m}^{2} \mathrm{yr}^{-1}$. It is worth noting that the success of wastewater treatment systems by means of using aquatic macrophytes is also determined by its growth rate. According to Greenway (2002), at low to medium nutrient concentrations, the biomass generation is proportional to nutrient supply [56].

7.2. Harvesting Period. It is worth highlighting that regular aquatic macrophytes harvesting is crucial in order to prevent the release of stored ammoniacal nitrogen back into the wastewater. Hence, a well-planned harvesting schedule is of utmost importance in order to ensure an efficient ammoniacal nitrogen removal. Table 6 displays the leaf lifespan of the different types of aquatic macrophytes.

Some of the leaf lifespan of aquatic macrophytes is affected by the dissolved inorganic nitrogen concentrations. Tsuchiya and Iwakuma (1993) discerned that the nutrient level may affect the leaf lifespan of Hydrocharis dubia L. [40]. The results of their study showed that the leaf lifespan is relatively longer in lower concentration of nutrients [40]. Tsuchiya (1989) revealed that the leaf lifespan of Trapa natans is shortened at higher nutrient concentrations (i.e., at $30 \mathrm{mg}$ N/L) [41]. Notably, Chabot and Hicks (1982) echoed that leaf lifespan is related to nutrient availability [65]. Eichhorna crassipes has the longest leaf lifespan, which is 35 days. Both Spirodela polyrhiza and Wolffia borealis have the lowest leaf lifespan, which is 12 days. It should be noted that the shorter the leaf lifespan of the aquatic macrophyte is, the more frequent it is to harvest the aquatic macrophytes. However, the leaf lifespan of aquatic macrophytes also depends on the characteristics of the wastewater, which is very sensitive heavy metal exposure (shown in Table 4).

\section{Sustainable Management of Harvested Aquatic Macrophytes}

Seadon (2010) posits that a sustainable waste management integrates feedback loops and avoid wastes from disposal [66]. Aquatic macrophytes is an organic matter, which can be broken down and can be converted into value-added products.

8.1. Biogas. Biogas is an environmentally clean fuel, which is generated from the anaerobic digestion of organic waste [67]. To generate biogas, aquatic macrophytes may be used due to its high carbon to nitrogen ratio and high content of fermentable matter [68]. Aquatic macrophytes, such as Eichhornia crassipes, Trapa natans, Typha latifolia, Salvinia molesta, Lemna minor, and Pistia stratiotes, can generate high biogas yield and be decomposed easily ([69-73]). Ngoju et al. (2015) stated that Eichhornia crassipes can be a potential feedstock for biogas generation. Also, they found that the biogas generated from Eichhornia crassipes feedstock comprised $49-53 \%$ of methane, $30-34 \%$ of carbon dioxide, $5-6 \%$ nitrogen, and relatively small amount of hydrogen sulphide [74]. On the other hand, factors affecting biogas yield from the aquatic macrophytes biomass include particle size, volatile solid content, plant composition (i.e., nitrogen, carbon, and phosphorus), trace nutrients, and inoculum volume [74]. According to Kathusi (2016), biogas generated from harvested aquatic macrophytes has the potential to be an effective strategy in reducing environmental problems with regard to top climate change, phytoremediation, eutrophication, acidification, and water pollution [75]. Besides that, Kathusi (2016) also concluded that biogas production from harvested aquatic macrophytes is commercially potential 
and sustainable [76]. Verma et al. (2007) discerned that the biogas generated from an Eichhornia crassipes and Trapa natans grown in brass and electroplating industry effluent was relatively higher due to the presence of various pollutants acting as a micronutrients for the aquatic macrophytes. They found that aquatic macrophytes grown in polluted wastewater increase the economic success of the energy generation from waste [77].

8.2. Vermicompost. The product of microbial degeneration of organic waste by using earthworms is known as vermicompost. Vermicompost is found to be rich with nutrients [78]. Bernal and Hernandez (2016) revealed that vermicompost from Eichhornia crassipes can be used as organic fertilizer or soil enhancer as it is rich in nutrients [79]. Furthermore, vermicompost from Eichhornia crassipes can be economical; it can be used to produce vermicompost in bulk by means of using the "high-rate method" and subjecting the vermicomposting in reactors with higher amount of earthworm than suggested hitherto [78]. Kostecka and Kaniuczak (2008) found that Lemna minor vermicompost is odourless with a good granular structure [80]. An efficient vermicomposting of Salvinia molesta with "high-rate" vermicompost technology using Eudrilus engeniae developed by Gajalakshmi et al. (2014) may be employed for vermicomposting as it is faster and economical [78]. Mishra et al. (2016) discovered that phytoremediated aquatic macrophytes biomass into vermicompost is effective and environmentally friendly for sustainable agriculture [81]. Among the aquatic macrophytes used by Mishra et al. (2016) are Azolla microphylla, Pistia stratiotes, Salvinia cucullata, and Salvinia molesta [81]. According to Tereshchenko and Akimova (2014), the employment of Eichhornia crassipes in vermicomposting helps improve the biometric parameters in a 14-day experiment, even the trial with water hyacinth biomass grown in wastewater contaminated with heavy metals [82]. Moreover, they suggested that vermicompost from heavy metal laden Eichhornia crassipes may be used as soil for urban landscaping and rehabilitation of technologically disturbed sites [82]. Hence, vermicomposting can be a sustainable tool for sustainable management of the harvested aquatic macrophytes.

8.3. Papermaking. It is noteworthy that aquatic macrophytes are suitable with the aqueous characteristics of paper pulp due to their high moisture content [83]. Bidin et al. (2015) reported that aquatic macrophytes, namely, Scirpus grossus, Cyperus rotundus, and Typha angustifolia can be used in papermaking due to their fiber characteristics, chemical composition, and physical properties [84]. Goswami and Saikia (1994) concluded that Eichhornia crassipes pulp can be an ideal raw material for greaseproof paper production, when it is mixed with bamboo pulp [85]. Moreover, Thomas and Room (1986) reported that Salvinia molesta is suitable for the papermaking [86]. Nevertheless, the researchers deem that more research is needed with regard to the industrial application in order to ensure the sustainability of this process.

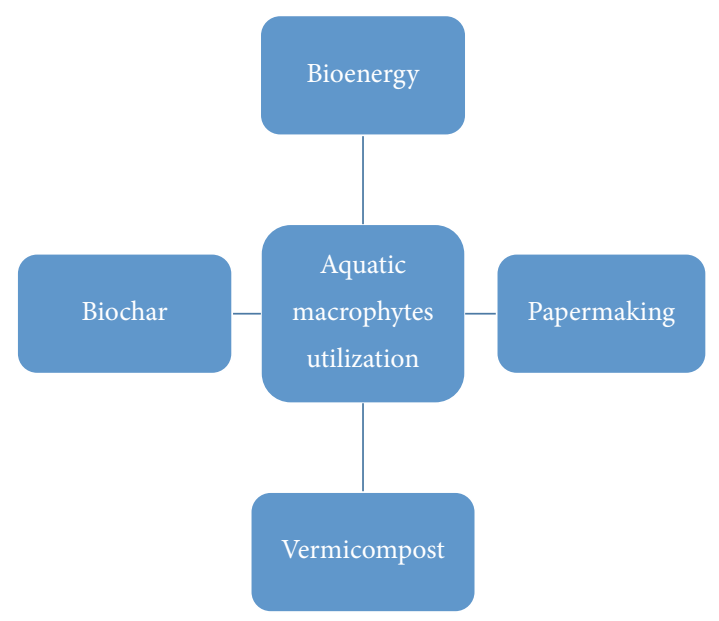

FIGURE 1: Summarization of the potential utilization of harvested aquatic macrophytes for industrial application.

8.4. Biochar. Biochar is comprised of carbon-rich material generated from organic waste [87]. Miranda et al. (2014) investigated the potential of the harvested biomass of L. punctata, Elodea, and Marsilea from Selenium-rich wastewater as a feedstock for the production of biochar by means of using pyrolysis technology [88]. They found that the pyrolysis product of Lemna minor can be converted into gasoline and diesel [88]. Apart from that, Masto et al. (2013) reported that biochar from Eichhornia crassipes can be utilized as soil quality amendment [89]. By converting harvested aquatic macrophytes biomass grown in wastewater contaminated with heavy metals by pyrolysis, the accumulated heavy metal can be enclosed safely in the solid fraction of the char. The summarizations of sustainable waste management of the harvested aquatic macrophytes can be summarized in Figure 1.

\section{Future Perspective}

As regards the conventional ammoniacal nitrogen clean-up technology, phytoremediation offers a sustainable option for tertiary industrial wastewater treatment. Hence, a greater need for improving its efficiency for industrial application is of utmost importance due to the fact that it is environmentally friendly and cost-effective. However, phytoremediation is both time and space consuming because large surface area is required in order to retain the wastewater. Consequently, studies focusing on the development of phytoremediation reactor, which may reduce the surface area for larger volumes of wastewater and its longer retention time, are deemed necessary. Apart from that, it should be noted that phytoremediation standalone system is a less efficient and timeconsuming process. Thus, the researchers deem that hybrid system of phytoremediation has the potential to increase the efficiency of phytoremediation. Putra et al. (2015) in their study of "Removal of Lead and Copper from Contaminated Water Using EAPR System and Uptake by Water Lettuce (Pistia Stratiotes L.)" reported that the overall metal uptake 
in plant system was higher under EAPR system compared to phytoremediation process [90]. Putra et al. (2015) concluded that the preliminary outcome of the experiment showed promising results in creating an inexpensive, eco-friendly hybrid system of electroassisted and phytoremediation system for the remediation of lead and copper contaminated wastewater [90]. Hence, more research and innovation on the different types of phytoremediation hybrid system in improving the efficiency and reliability of this green remediation technology for different types of wastewater contaminants are needed.

\section{Conclusion}

Based on the findings of the present study, it can be concluded that phytoremediation of nitrogen by means of using aquatic macrophytes possessed green chemistry characteristics. Moreover, it has been proven that the green chemistry characteristics of phytoremediation is sustainable and cost-effective in relation to other existing ammoniacal nitrogen remediation technology. Apart from that, Eichhornia crassipes appeared to be one of the most promising aquatic macrophytes for wastewater treatment due to its high tolerance with wide range of wastewater contaminants. Nevertheless, several parameters are deemed necessary to be taken into consideration in order to ensure the efficiency of the phytoremediation of ammoniacal nitrogen. Besides that, appropriate method for the removal of the harvested macrophytes must also be considered to ensure the sustainability of the phytoremediation process. Converting the harvested aquatic macrophytes into biogas and vermicompost can be a promising technique for a sustainable waste management for the phytoremediation process as proved by several researchers. However, more research is still needed for the conversion of the aquatic macrophytes into papermaking material and biochar. Notably, the hybrid system of phytoremediation for wastewater treatment may be a popular trend in the near future due to its cost effectiveness and increased efficiency in remediating wastewater.

\section{Conflicts of Interest}

The authors declare that there are no conflicts of interest regarding the publication of this article.

\section{References}

[1] S. B. Watson, B. A. Whitton, S. Higgins, and J. D. Wehr, Harmful Algal Blooms. Freshwater Algae of North America, vol. 20, Academic Press, 2nd, Chapter 20 edition, 2015.

[2] P. Gupta, S. Roy, and A. B. Mahindrakar, "Treatment of water using water hyacinth, water lettuce and vetiver grass - a review," Resources and Environment, vol. 2, no. 5, pp. 202-215, 2012.

[3] B. Clément and G. Merlin, "The contribution of ammonia and alkalinity to landfill leachate toxicity to duckweed," Science of the Total Environment, vol. 170, no. 1-2, pp. 71-79, 1995.

[4] K. Emerson, R. E. Lund, R. V. Thurston, and R. C. Russo, "Aqueous ammonia equilibrium calculations: effect of $\mathrm{pH}$ and temperature," Journal of Fisheries Research Board of Canada, vol. 32, pp. 2379-2383, 1975.

[5] M. Constable, M. Charlton, F. Jensen, and K. W. Taylor, "An ecological risk assessment of ammonia in the aquatic environment," Human and Ecological Risk Assessment, vol. 9, no. 2, pp. 527-548, 2003.

[6] S. A. Alrumman, A. El-kott, and S. M. A. S. Keshk, "Water pollution: source and treatment," American Journal of Environmental Engineering, vol. 6, no. 3, pp. 88-98, 2016.

[7] F. M. Ferraz, J. Povinelli, and E. M. Viera, "Ammonia removal from landfill leachaye by air stripping," Environmental Technology, vol. 34, no. 15, pp. 2317-2326, 2013.

[8] Battele-Northwest Richland, Wastewater Ammonia Removal by Ion Exchange, 1971, February 2017 https://nepis.epa.gov/Exe/ ZyPDF.cgi/9100GI2P.PDF?Dockey=9100GI2P.PDF.

[9] T. A. Pressley, D. F. Bishop, A. P. Pinto, and A. P. Cassel, Ammonia- Nitrogen Removal by Breakpoint Chlorination, 1973, February 2017 https://nepis.epa.gov/Exe/ZyPDF.cgi/91020N8G .PDF?Dockey=91020N8G.PDF.

[10] M. Mondor, L. Masse, D. Ippersiel, F. Lamarche, and D. I. Massé, "Use of electrodialysis and reverse osmosis for the recovery and concentration of ammonia from swine manure," Bioresource Technology, vol. 99, no. 15, pp. 7363-7368, 2008.

[11] Y. Y. Fang, X. E. Yang, H. Q. Chang, P. M. Pu, X. F. Ding, and Z. Rengel, "Phytoremediation of nitrogen-polluted water using water hyacinth," Journal of Plant Nutrition, vol. 30, no. 11, pp. 1753-1765, 2007.

[12] Organics Limited, SystEms for Ammonia Removal from Landfill Leachate, 2016, December 2016 http://www.organics.co.uk/en/ products/20/ammonia-stripping-systems.

[13] R. G. Rice, C. M. Robson, G. W. G. Miller, J. C. Clark, and W. Kohn, Biological Processes in the Treatment of Municipal Water Supplies, 1982, February 2017 https://nepis.epa.gov/Exe/ZyPDF. .cgi/9100LYD1.PDF?Dockey=9100LYD1.PDF.

[14] K. Y. Oh, T. H. Cao, T. Li, and H. Y. Cheng, "Study on application of phytoremediation technology in management and remediation of contaminated soils," Journal of Clean Technologies, vol. 2, no. 3, pp. 216-220, 2014.

[15] J. C. Campos, D. Moura, A. P. Costa, L. Yokoyama, F. V. D. F. Araujo, and M. C. Cammarota, "Evaluation of $\mathrm{pH}$, alkalinity and temperature during air stripping process for ammonia removal from landfill leachate," Journal of Environmental Science and Health, vol. 48, no. 9, pp. 1105-1113, 2013.

[16] K. Okada, M. Akiyoshi, K. Ishizaki, H. Sato, and T. Matsunaga, "Analysis of an explosion accident of nitrogen trichloride in a waste liquid containing ammonium ion and platinum black," Journal of Hazardous Materials, vol. 278, pp. 75-81, 2014.

[17] R. Warrier, Phytoremediation for Environmental Clean up. Forestry Bulletin, 2012, February 2017 http://www.frienvis.nic .in/WriteReadData/UserFiles/file/Content-Page/Vol-12-No-2/ Vol-12-No-2-0-Phytoremediation-for-environmental.pdf.

[18] X. M. Lu, M. Kruatrachue, P. Pokethitiyook, and K. Homyok, "Removal of cadmium and zinc by water hyacinth, eichornia crassipes," ScienceAsia, vol. 30, pp. 93-103, 2004.

[19] S. Das, S. Goswami, and A. Das Talukdar, "Physiological responses of water hyacinth, eichhornia crassipes (Mart.) solms, to cadmium and its phytoremediation potential," Turkish Journal of Biology, vol. 40, no. 1, pp. 84-94, 2016.

[20] A. Basile, S. Sorbo, B. Conte et al., "Toxicity, accumulation, and removal of heavy metals by three aquatic macrophytes," International Journal of Phytoremediation, vol. 14, no. 4, pp. 374387, 2012. 
[21] L. B. Chanu and A. Gupta, "Toxicity of zinc on growth of aquatic macrophyte, ipomea aquatica forsk," Current World Environment, vol. 11, no. 1, pp. 218-227, 2016.

[22] T. Vesely, M. Neuberg, and L. Trakal, "Water lettuce Pistia Stratiotes L. response to lead toxicity," Water, Air, and Soil Pollution, vol. 223, no. 4, pp. 1847-1859, 2012.

[23] M. Ebel, M. W. Evangelou, and A. Schaeffer, "Cyanide phytoremediation by water hyacinth," Chemosphere, vol. 66, pp. 816823, 2007.

[24] R. Pal and J. P. N. Rai, "The phytoextraction potential of water hyacinth (Eichornia Crassipes): removal of selenium and copper," International Journal of Phytoremediation, vol. 26, no. 3, pp. 163-172, 2010.

[25] A. Chantiratikul, P. Atiwetin, and P. Chantiratikul, "Feasibility of producing selenium-enriched water lettuce (Pistia stratiotes L.)," Journal of Biological Sciences, vol. 8, no. 3, pp. 644-648, 2008.

[26] E. Melignani, L. I. de Cabo, and A. M. Faggi, "Copper uptake by Eichhornia Crassipes exposed at high level concentrations," Environmental Science and Pollution Research, vol. 22, no. 11, pp. 8307-8315, 2015.

[27] B. Mukherjee, M. Majumdar, A. Gangopadhyay, S. Chakraborty, and D. Chaterjee, "Phytoremediation of parboiled rice mill wastewater using water lettuce (Pistia Stratiotes)," International Journal of Phytoremediation, vol. 17, no. 7, pp. 651-656, 2015.

[28] S. Malar, S. S. Vikram, P. JC. Favas, and V. Perumal, "Lead heavy metal toxicity induced changes on growth and antioxidative enzymes level in water hyacinth (Eichornia Crassipes (Mart))," Botanical Studies, vol. 55, p. 54, 2014.

[29] H. Kousar and M. Pavithra, "Efficiency of water hyacinth (Eichornia Crassipes) in reduction of chemical oxygen demand (COD) from textile effluent," Imperial Journal of Interdisciplinary Research, vol. 2, no. 7, pp. 1071-1073, 2016.

[30] Y. Nuraini and M. Felani, "Phytoremediation of tapioca wastewater using water hyacinth plant (Eichornia Crassipes)," Journal of Degraded and Mining Land management, vol. 2, no. 2, pp. 295302, 2015.

[31] B. B. Ayade, "Development of toxicity tolerant water hyacinth (Eichhornea Crassipes) for effective treatment of raw sewage," Acta Biotechnologica, vol. 18, no. 1, pp. 43-50, 1998.

[32] R. D. Sooknah and A. C. Wilkie, "Nutrient removal by floating aquatic macrophytes cultured in anaerobically digested flushed dairy manure wastewater," Ecological Engineering, vol. 22, no. 1, pp. 27-42, 2004.

[33] W. Wang, "Ammonia toxicity to macrophytes (common duckweed and rice) using static and renewal methods," Environmental Toxicology and Chemistry, vol. 10, no. 9, pp. 1173-1177, 1991.

[34] K. R. Reddy and J. C. Tucker, "Productivity and nutrient uptake of water hyacinth, Eichhornia Crassipes I. Effect of nitrogen source," Economic Botany, vol. 37, no. 2, pp. 237-247, 1983.

[35] M. Komulainen, P. Simi, E. Hagelberg, I. Ikonen, and S. Lyytinen, Reed Energy - Possibilites of Using the Common Reed Energy for Energy Generation in Southern Finland. Reports from Turku University of Applied Sciences, vol. 18, 2008, April 2017 http://julkaisut.turkuamk.fi/isbn9789522160355.pdf.

[36] D. D. Culley, E. Rejmánková, J. Květ, and J. B. Frye, "Production, chemical quality and use of duckweeds (Lemnaceae) In aquaculture, waste management, and animal feeds," Journal of the World Mariculture Society, vol. 12, pp. 27-49, 1981.

[37] K. R. Reddy and J. C. Tucker, "Growth and nutrient uptake of pennyworth (Hydrocotyle Umbellata L.). as influenced by the nitrogen concentration of the water," Journal of Aquatic Plant Management, vol. 23, pp. 35-40, 1985.

[38] T. D. Center and N. R. Spencer, "The phenology and growth of water hyacinth (Eichhornia crasippes Mart. (Solms) in an eutrophic north-central florida," Aquatic Botany, vol. 10, pp. 132, 1981.

[39] H. Kunii and M. Aramaki, "Annual net production and life span of floating leaves in Nymphaea tetragona Georgi: a comparison with other floating-leaved macrophytes," Hydrobiologia, vol. 242, no. 3, pp. 185-193, 1992.

[40] T. Tsuchiya and T. Iwakuma, "Growth and leaf life-span of a floating-leaved plant, Trapa natans L., as influenced by nitrogen flux," Aquatic Botany, vol. 46, no. 3-4, pp. 317-324, 1993.

[41] T. Tsuchiya, "Growth and biomass turnover of Hydrocharis Dubia L. cultured under different nutrient conditions," Ecological Research, vol. 4, no. 2, pp. 157-166, 1989.

[42] G. D. Lemon, U. Posluszny, and B. C. Husband, "Potential and realized rates of vegetative reproduction in Spirodela polyrhiza, Lemna minor, and Wolffia borealis," Aquatic Botany, vol. 70, no. 1, pp. 79-87, 2001.

[43] The National Science and Technology Council, An Assessment of Coastal Hypoxia and Eutrophication in U.S. Waters. U.S.A. Retrieved at On, 24th, United States. Office of Science and Technology Policy, Washington, USA, 2003, http://oceanservice .noaa.gov/outreach/pdfs/coastalhypoxia.pdf.

[44] C. Masclaux-Daubresse, F. Daniel-Vedele, J. Dechorgnat, F. Chardon, L. Gaufichon, and A. Suzuki, "Nitrogen uptake, assimilation and remobilization in plants: challenges for sustainable and productive agriculture," Annals of Botany, vol. 105, no. 7, pp. 1141-1157, 2010.

[45] M. Fried, F. Zsoldos, P. B. Vose, and I. L. Shatokhin, "Characterizing the $\mathrm{NO}^{-}$and $\mathrm{NH}_{4}^{+}$uptake process of rice roots by use of ${ }^{15} \mathrm{~N}$ labelled $\mathrm{NH}_{4} \mathrm{NO}_{3}$," Physiologia Plantarum, vol. 18, no. 2, pp. 313-320, 1965.

[46] A. Jampeetong and H. Brix, "Oxygen stress in salvinia natans: interactive effects of oxygen availability and nitrogen source," Environmental and Experimental Botany, vol. 66, no. 2, pp. 153159, 2009.

[47] G. N. Mitra, Regulation of Nutrient Uptake by Plants, Springer, Odisha, India, 2015.

[48] N. Mattson and R. Leatherwood, Nitrogen: All Forms Are Not Equal, 23rd, 23rd edition, 2009, February 2017 http://www .greenhouse.cornell.edu/crops/factsheets/nitrogen_form.pdf.

[49] EPA, Green Chemistry, 2016, December 2016 https://www.epa .gov/greenchemistry.

[50] S. D. Cunningham and D. W. Ow, "Promises and prospects of phytoremediation," Plant Physiology, vol. 110, no. 3, pp. 715-719, 1996.

[51] P. Viotti and R. Gavasci, "Scaling of ammonia stripping towers in the treatment of groundwater polluted by municipal solid waste landfill leachate: study of the causes of scaling and its effects on stripping performance," Revista Ambiente and Agua, vol. 10, no. 2, pp. 241-252, 2015.

[52] M. Datoni and S. Longo, "Monitoring and diagnosis of energy consumption in wastewater treatment plants. A state of the art and proposals for improvement," Applied Energy, vol. 179, pp. 1251-1268, 2016.

[53] C. R. Che Hassan, B. Puvaneswaran, A. R. Aziz, M. Noor Zalina, F. C. Hung, and N. M. Sulaiman, "Quantitative risk assessment for the transport of ammonia by rail," Process Safety Progress, vol. 29, no. 1, pp. 60-63, 2010. 
[54] E. Clarke and A. H. Baldwin, "Responses of wetland plants to ammonia and water level," Ecological Engineering, vol. 18, no. 3, pp. 257-264, 2002.

[55] S. C. Lin, G. W. Ye, J. Z. Wu, Y. B. Zheng, and W. X. Lin, "Studies on the Comparison of the Chemical Compounds in Lotus Seeds (Nelumbo nucifera Gaertn.) Between "Tai-Kong lotus 36" and "Jian lotus"," Strait Pharmaceutical Journal, vol. 17, no. 4, pp. 9193, 2005.

[56] M. Greenway, "Suitability of macrophytes for nutrient removal from surface flow constructed wetlands receiving secondary treated sewage effluent in Queensland, Australia," Water Science and Technology, vol. 48, no. 2, pp. 211-218, 2003.

[57] W. T. Haller, D. L. Sutton, and W. C. Barlowe, "Effect of salinity on growth of several aquatic macrophytes," Ecology, vol. 55, no. 4, pp. 891-894, 1974.

[58] Q. Lu, Evaluation of Aquatic Plants for Phytoremediation of Eutrophic, Stormwaters [phd disscution], University of Florida, Fla, USA, 2009.

[59] S. De Pascale, G. Barbieri, and C. Ruggiero, "Effects salinity on plant growth and water relations in Phaseolus vulgaris L.," Acta Horticulturae, vol. 449, no. 2, pp. 649-655, 1997.

[60] M. Shah, H. N. Hashimi, A. Ali, and A. R. Ghumman, "Performance assessment of aquatic macrophytes for treatment of municipal wastewater," Journal of Environment Health Science and Engineering, vol. 12, no. 1, p. 106, 2014.

[61] S. Perdomo, M. Fujita, M. Ike, and M. Tateda, Growth Dynamics of Pistia Stratiotes in Temperate Climate: Wastewater Treatment, Plant Dynamics and Management in Constructed and Natural Wetlands, Springer, Amsterdam, The Netherlands, 2008.

[62] K. R. Reddy and W. F. Debusk, "Nutrient removal potential of selected aquatic macrophytes," Journal Environment Quality, vol. 14, pp. 459-462, 1985.

[63] A. S. El-Gendy, N. Biswas, and J. K. Bewtra, "Growth of water hyacinth in municipal landfill leachate with different $\mathrm{pH}$," Environmental Technology, vol. 25, no. 7, pp. 833-840, 2004.

[64] N. S. Rathore and N. L. Panwar, Renewable Energy Sources for Sustainable Development, New India Publishing Agency, Pitam Pura, New Delhi, India, 2007.

[65] B. F. Chabot and D. J. Hicks, "The ecology of leaf life spans," Annual review of ecology and systematics, vol. 13, pp. 229-259, 1982.

[66] J. K. Seadon, "Sustainable waste management systems," Journal of Cleaner Production, vol. 18, no. 16-17, pp. 1639-1651, 2010.

[67] S. Yadvika, T. R. Sreekrishnan, S. Kohli, and V. Rana, "Enhancement of biogas production from solid substrates using different techniques-a review," Bioresource Technology, vol. 95, no. 1, pp. $1-10,2004$.

[68] J. E. Hronich, L. Martin, H. Bungay, and J. Plawsky, "Potential of Eichhornia Crassipes for biomass refining," Journal of Industrial Microbiology and Biotechnology, vol. 35, no. 5, pp. 393-402, 2008.

[69] C. G. Gunnerson and D. C. Stuckey, Anaerobic Digestion: Principles and Practices for Biogas Systems, The World Bank, Washington, USA, 1986.

[70] K. Sudhakar, R. Ananthakrishnan, and A. Goyal, "Biogas production from a mixture of water hyacinth, water chestnut and cow dung," International Journal of Science, Engineering and Technology Research, vol. 2, no. 1, pp. 35-37, 2013.

[71] A. K. Mathew, I. Bhui, S. N. Banerjee et al., "Biogas production from locally available aquatic weeds of Santiniketan through anaerobic digestion," Clean Technologies and Environmental Policy, vol. 17, no. 6, pp. 1681-1688, 2015.
[72] Ström, Leachate Treatment Andanaerobic Digestion Using Aquatic Plants Andalgae [Ms.c thesis], The Tema Institute, Linköping University, Sweden, 2010.

[73] R. Pantawong, A. Chuanchai, P. Thipbunrat, Y. Unpaprom, and R. Ramaraj, "Experimental investigation of biogas production from water lettuce, Pistia Stratiotes L.," Emergent Life Sciences Research, vol. 1, no. 2, pp. 14-46, 2015.

[74] P. Njogu, R. Kinyua, P. Muthoni, and Y. Nemoto, "Biogas production using water hyacinth (Eicchornia Crassipes) for electricity generation in Kenya," Energy and Power Engineering, vol. 7, no. 5, pp. 209-216, 2015.

[75] K. K. Moorhead and R. A. Nordstedt, "Batch anaerobic digestion of water hyacinth: effects of particle size, plant nitrogen content, and inoculum volume," Bioresource Technology, vol. 44, no. 1, pp. 71-76, 1993.

[76] Kathusi. S., Bioenergy from Phytoremediated Phytomass of Aquatic Plants via Gasification. Bioremediation and Bioeconomy, 2016, April 2017 https://www.researchgate.net/publication/ 282910052_Bioenergy_from_Phytoremediated_Phytomass_of_ Aquatic_Plants_via_Gasification.

[77] V. K. Verma, Y. P. Singh, and J. P. N. Rai, "Biogas production from plant biomass used for phytoremediation of industrial wastes," Bioresource Technology, vol. 98, no. 8, pp. 1664-1669, 2007.

[78] S. Gajalakshmi, E. V. Ramasamy, and S. A. Abbasi, "High-rate composting-vermicomposting of water hyacinth (Eichhornia Crassipes, Mart. Solms)," Bioresource Technology, vol. 83, no. 3, pp. 235-239, 2002.

[79] D. A. Bernal and M. A. L. Hernandez, "Vermicompost as an alternative of management for water hyacinth," International Journal of Environmental Pollution, vol. 32, no. 4, pp. 425-433, 2016.

[80] J. Kostecka and J. Kaniuczak, "Vermicomposting of duckweed (Lemna Minor 1.) biomass by Eisenia Fetida (sav.) earthworm," Journal of Elementology, vol. 13, no. 4, pp. 571-579, 2008.

[81] M. Mishra, A. Mohapatra, and K. B. Satapathy, "A Comparative study of vermicompost prepared from phytoremediated and naturally grown aquatic weeds on growth and yield of green gram [Vigna radiata (L.) Wilczek]," International Journal of Current Research in Biosciences and Plant Biology, vol. 3, no. 7, pp. 104-109, 2016.

[82] N. N. Tereshchenko, E. E. Akimova, A. D. Pisarchuk, T. V. Yunusova, and O. M. Minaeva, "Utilizing heavy metal-laden water hyacinth biomass in vermicomposting," Environmental Science and Pollution Research, vol. 22, no. 9, pp. 7147-7154, 2015.

[83] J. Asunción, The Complete Book of Paper Making, Lark Books, Barcelona, Spain, 2003.

[84] N. Bidin, M. H. Zakaria, J. S. Bujang, and N. A. Abdul Aziz, "Suitability of aquatic plant fibers for handmade papermaking," International Journal of Polymer Science, vol. 2015, no. 2015, Article ID 165868, pp. 1-9, 2015.

[85] T. Goswami and C. N. Saikia, "Water hyacinth-a potential source of raw material for greaseproof paper," Bioresource Technology, vol. 50, no. 3, pp. 235-238, 1994.

[86] P. A. Thomas and P. M. Room, "Taxonomy and control of Salvinia molesta," Nature, vol. 320, pp. 581-584, 1986.

[87] K. Kameyama, T. Miyamoto, T. Shiono, and Y. Shinogi, "Influence of sugarcane bagasse-derived biochar application on nitrate leaching in calcaric dark red soil," Journal of Environmental Quality, vol. 41, no. 4, pp. 1131-1137, 2011. 
[88] A. F. Miranda, N. A. Muradov, A. Gujar et al., "Application of aquatic plants for the treatment of selenium-rich mining wastewater and production of renewable fuels and petrochemicals," Journal of Sustainable Bioenergy Systems, vol. 4, pp. 97-112, 2014.

[89] R. E. Masto, S. Kumar, T. K. Rout, P. Sarkar, J. George, and L. C. Ram, "Biochar from water hyacinth (Eichornia Crassipes) and its impact on soil biological activity," Catena, vol. 111, pp. 64-71, 2013.

[90] R. S. Putra, F. Cahyana, and D. Novarita, Removal of Lead and Copper from Contaminated Water Using EAPR System and Uptake by Water Lettuce, 2015, February 2017 http://www .sciencedirect.com/science/article/pii/S1876619615000534. 


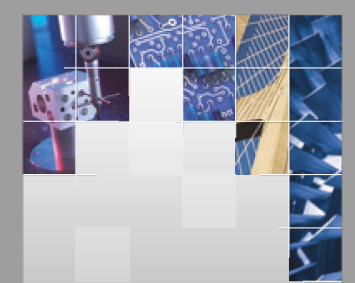

\section{Enfincering}
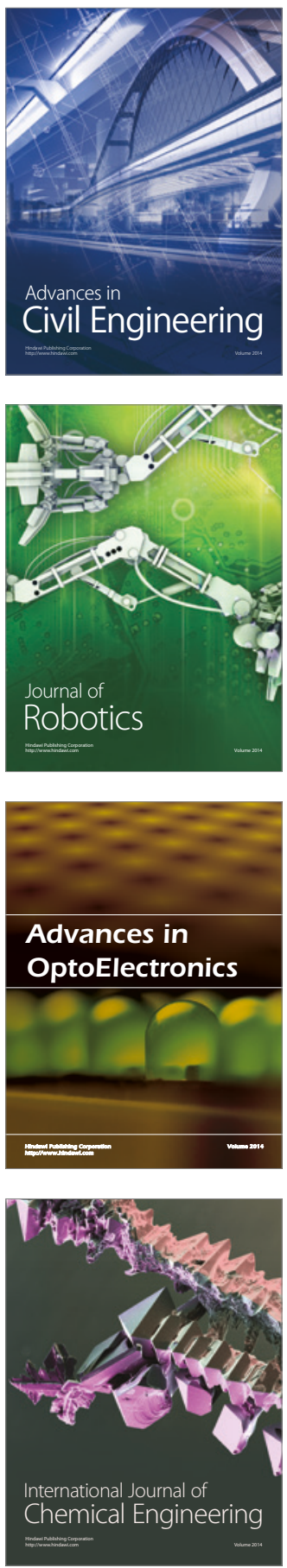

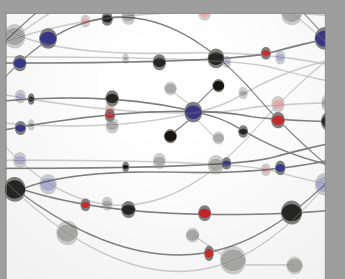

The Scientific World Journal

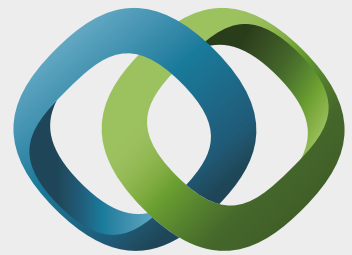

\section{Hindawi}

Submit your manuscripts at

https://www.hindawi.com
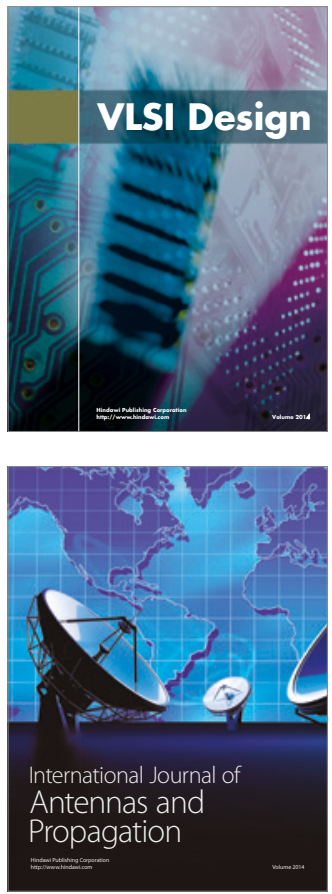

\section{Rotating}

Machinery
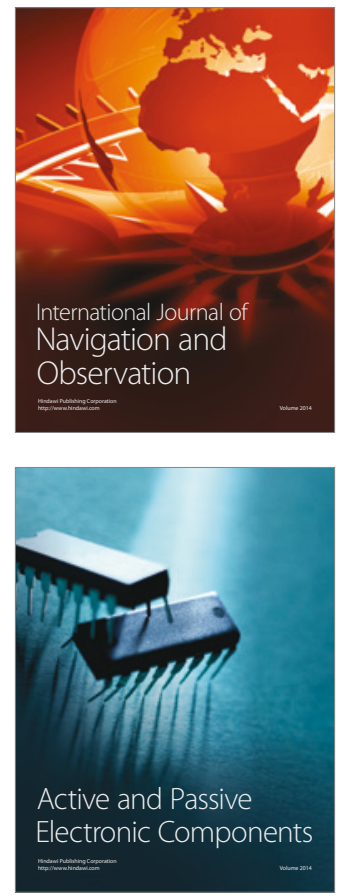
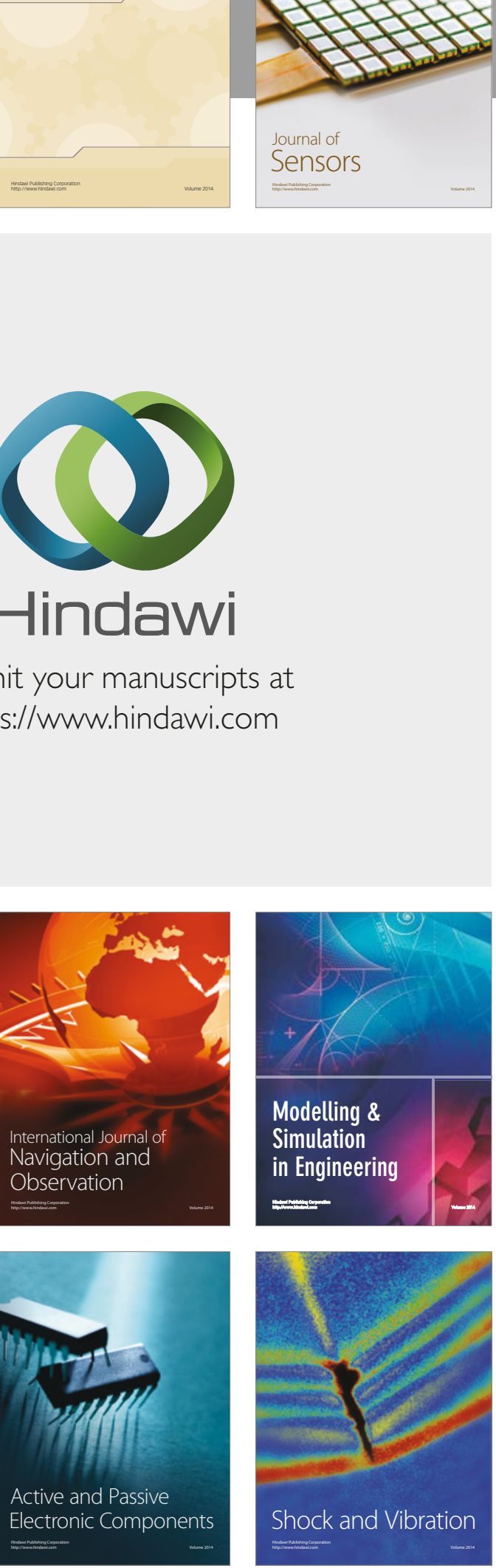
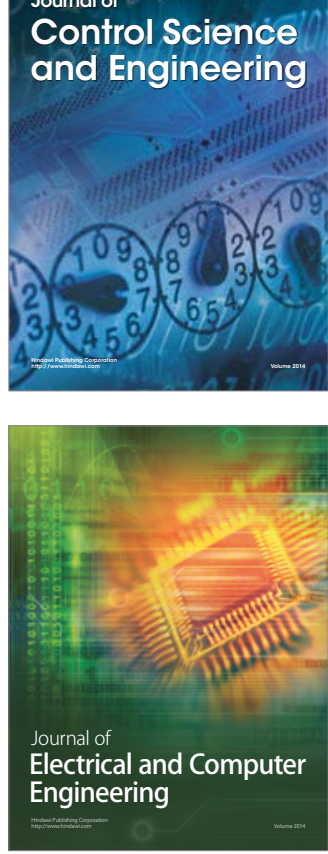

Distributed

Journal of

Control Science

and Engineering
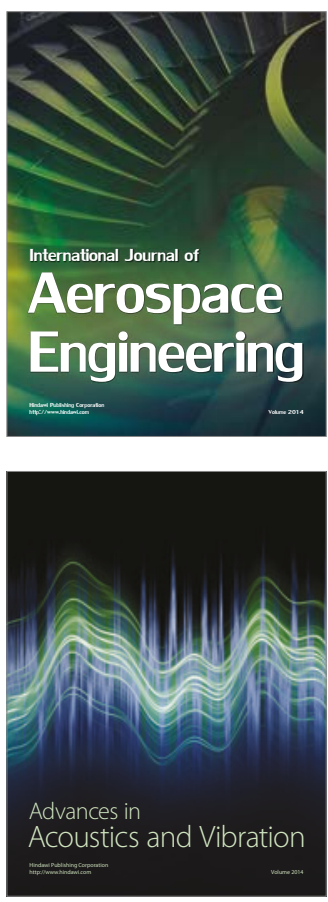

Sensor Networks 